\title{
Entry Date from Country of Potential Disease Exposure
}

National Cancer Institute

\section{Source}

National Cancer Institute. Entry Date from Country of Potential Disease Exposure. NCI

Thesaurus. Code C102631.

The date on which the subject arrived in the reporting country from the country of potential disease exposure. 